\title{
The differential impacts of customer commitment dimensions on loyalty in the banking sector in Jordan: Moderating the effect of e-service quality
}

\author{
Ahmad Khraiwish $^{a^{*}}$, Jassim Ahmad Al-Gasawneh ${ }^{a}$, Jamal M.M. Joudeha, Nawras M. Nusairat ${ }^{\text {a }}$ \\ and Yaser F. Alabdi ${ }^{b}$
}

${ }^{a}$ Marketing Department, Faculty of Business, Applied Science Private University, Amman, 11931, Jordan

${ }^{b}$ Marketing Department, Talal Abu Ghazaleh University College for Innovation (TAGUCI), Amman, Jordan

\section{H R O N I C L E \\ A B S T R A C T}

\author{
Article history: \\ Received: October 26, 2021 \\ Received in revised format: No- \\ vember 22, 2021 \\ Accepted: January 16, 2022 \\ Available online: January 162022 \\ Keywords: \\ Islamic banks \\ Conventional banks \\ e-service quality (e-SQ) \\ Affective commitment (AC) \\ Normative commitment (NC) \\ Calculative commitment (CC) \\ Customer loyalty \\ Jordan
}

\begin{abstract}
The current research scrutinizes the relationship between the three model commitment components (affective, normative, and calculative commitment) and their various influences on customer loyalty. This is particularly in the banking sector setting in Jordan. A self-reported questionnaire was distributed to collect primary data for analysis. 333 completed questionnaires were analyzed via using PLS software to extract the effect of e-service quality on the relationship between customer commitment and loyalty. The results of this study demonstrate that the affective type of commitment has a positive impact on customer loyalty followed by normative commitment and lately by calculative commitment. Moreover, the results show that the influence of the dimensions of customer's commitment on loyalty is moderated by e-service quality. This study indicates that affective commitment elements (self-identification, sense of belonging and emotional attitudinal components) are essential for customers when they deal with their bank. On the other hand, the cost associated with leaving has shown to have the weakest impact on customer loyalty. Companies must know that customers may switch even though the cost associated with leaving is high.
\end{abstract}

\section{Introduction}

The influence of technology and the increase of market competitions have made customer's negotiating ability more robust than ever before. Companies are required to attentively notice both concepts of customer commitment and customer loyalty to gain and hold onto profitable customers in vibrant and competitive markets. Hence, customers are considered as key elements for any organization, especially for growth, resource allocation, marketing strategies as well as profitability (Reinart et al., 2004). This customer-organization relationship increases the need for comprehensive research in the relationship that connects customers to a service, a brand or a bank (Anderson \& Narus, 1991). Additionally, in the marketing literature, retaining existing customers is very crucial, same as attracting new customers especially in the banking sector setting. This is due to the arrangements that banks' customers have that might change their behavior and affect their intentions to switch to another provider. They suggested that this behavior results due to the high competition between retail banks and the similarity in services they offer. Consequently, to maintain existing customers, banks should focus on maintaining and increasing customer loyalty through providing better services. In recent years, customers are more technological literate and have more tendencies to use electronic services and are demanding for high automated service quality offered by businesses including

* Corresponding author.

E-mail address: a.khraiwish@asu.edu.jo (A. Khraiwish)

(C) 2022 by the authors; licensee Growing Science, Canada. doi: $10.5267 /$ j.ijdns.2022.1.006 
banks (Al-Hawari, 2011; Hawamleh et al., 2020; Al-Gasawneh et al., 2020). Consequently, the availability of high-quality services enhances customer retention rates as well as customer commitment to the business (Parasuraman et al., 2005).

For this purpose, researchers (e.g., Allen \& Meyer, 1990; Morgan \& Hunt, 1994) attempted to study the relationship between commitment and loyalty in different sectors and among different study samples including employees and customers. However, recognizing the relationship between commitment dimensions and customer loyalty suffers from lack of solid and robust, most importantly in the banking sector.

Research in the field of commitment has always been a fruitful field of study. However, it was discussed and adopted differently by researchers. The three components of commitment were firstly recognized in the literature of marketing through the study of Allen and Meyer (1990) who suggested that employee's commitment is classified into (affective, continuance (also known as calculative) and normative commitment). Later, Morgan and Hunt (1994) adopted the three dimensions model and studied the relationship between customer commitment and loyalty. This perspective on commitment offered scholars different areas of research in commitment and its influence on the variant relationships in question in different ways. Notwithstanding, in marketing literature, commitment was regarded differently throughout the years. For instance, Rusbult (1980) described a unidimensional commitment construct, which is more related to affective commitment. While other researchers in the relationship marketing field suggested two dimensions for commitment; affective (based on feelings of uniformity, loyalty and attachment) as well as calculative (or continuance) commitment based on expected cost of switchover (e.g., Fullerton, 2003; Gustafsson et al., 2005). Alternatively, Keiningham et al. (2015) claimed that commitment is classified as a five-dimension model when it comes to consumer commitment, including affective, economic, normative, habitual, and forced commitment. Yet, the broader body of research in relationship marketing literature and organizational behavior mainly study customer commitment based on the three dimensions model; affective, calculative and normative commitment (Bansal et al., 2004; Gruen et al., 2000; Jones et al., 2010; Fatima et al., 2015; Al-Adamat, Al-Gasawneh \& Al-Adamat, 2020).

Given the above, it is evident that the research in the commitment model in the literature is escalating (Stanley et al., 2013). Moreover, Gruen et al. (2000) study, proposed that the three-dimensional model of commitment can be applied in many different marketing research contexts. Adding to that, in the marketing literature, there is insufficient research on the area that studies the customer commitment model (affective, normative and calculative) that is related to customer loyalty in the banking setting. This is because most of the early research on studying commitment focused on employee's commitment and behavior (e.g. job behaviors and the intention to turnover) and neglected the outcomes that are customer-based (i.e. customer satisfaction and customer perceived relational benefits). Not paying attention to customer behavior has created a gap in the marketing literature, as it is not fully understood and acknowledged how customers with different commitment profiles value relationship-based features (Bansal et al., 2004; Stanley et al., 2013; Fatima \& Mascio, 2020). Adding to that understanding the effects of electronic banking service quality on customer commitment thus customer loyalty in the Jordanian context has received no attention in the services marketing area.

The current study thus aims to contribute to the body of marketing literature in general. Also, such research is considered particularly relevant to service marketing in particular as it deals with financial institutions (i.e., banks). To fill the gaps in the literature, the present study makes two specific contributions to current knowledge: first, the relationship between commitment dimensions and loyalty in purchasing services online is analyzed. As well, the moderating effect of e-service quality in the influence of the dimensions of commitment on loyalty is proven, all in which is conducted in the Jordanian context.

\section{Literature Review}

To define customer loyalty, researchers have investigated the concept from different perspectives. Dick and Basu (1994, p.100) defined the concept of customer commitment as a "relative attitude" from the customer side towards the institution and a favoritism behavior. From a different perspective, customer loyalty is defined by Oliver (1999, p. 34) as "a deeply held commitment to rebuy or re-patronize a preferred product or service consistently in the future, causing repetitive same brand or same brand-set purchasing, despite situational influences and marketing efforts". In addition, Daikh (2015) defined it as a natural commitment that causes the customer to either reuse a particular product or service or else to repurchase.

Customer loyalty was recognized by several studies, including studies for service marketing (McMullan \& Gilmore, 2008) who argued that customer loyalty can be achieved by giving customers the appropriate reward at different levels, also they highlighted the importance of reciprocity in line with which parts of a particular service customers appreciate the most. Nonetheless, Afsar et al. (2010) explored the factors of customer loyalty and their relationships with the banking industry in Pakistan. They found that perceived trust, commitment, satisfaction, quality, and switching cost to positively affect customer loyalty. While Rather and Sharma (2017) studied the relationship between customer satisfaction and commitment to customer loyalty in the hotel sector. Their findings showed that commitment is positively related to customer loyalty. Nonetheless the same relationship applied to satisfaction and loyalty as well as satisfaction and commitment.

Similar to the previous studies, the marketing literature has a pool of studies that distinguish between how commitment is perceived. Some suggest that commitment is related to the service provider (i.e. the person) while others believe it is more related to the service organization (i.e. banks, hotels, real estate companies) (Hansen et al., 2003; Jones et al., 2010). Therefore, 
this present study considered commitment in relation to service organization (i.e. banking sector) and its effect on customer loyalty.

\subsection{The concept of Commitment in marketing relationships}

The concept of commitment and its different relation has been widely studied in the organizational behavior literature, either as employees commitment to organizations (e.g., Allen \& Meyer 1990, 1996; Meyer \& Allen, 1991; Jaros et al., 1993; Alfakeh et al., 2020), or as the commitment of customers (e.g., Morgan \& Hunt, 1994; Brown et al., 2005; Stanley et al., 2013; Fatima \& Mascio, 2020). In addition, commitment to the services provider (e.g., Bansal et al., 2004; Jones et al., 2008; Wästerlund \& Kronholm, 2017; Alghasawneh et al., 2021), commitment to salespeople (e.g., Macintosh and Lockshin 1997; Hansen et al., 2003; Li et al., 2020; Al-Gasawneh \& Al-Adamat, 2020), and commitment to the brand (e.g., Johnson et al., 2006; Ramírez et al., 2017; Alkhawaldeh et al., 2017) were all investigated in the marketing literature.

Additionally, in relationship marketing, researchers suggest that when commitment is linked to an entire entity is more related to loyalty than when it is meant to certain individual aspects, such as employees (Macintosh \& Lockshin 1997; Hansen et al., 2003) or elsewise linked to a service provided by an entity (Bansal et al., 2004; Jones et al., 2007). In accordance with this view, researchers define commitment based on the mutual benefit that both parties will receive, therefore, it is looked at as an obligation between the two partners (customer and business) to progress the relationship (Dwyer et al., 1987) as well as to maintain it (Morgan_\& Hunt, 1994) or it can be the way how customers are reluctant to shift to another business (Pritchard et al., 1999). Contrariwise, Meyer and Herscovitch (2001) defined commitment as the power that connects both parties (customers and businesses) to receive the mutual benefit. The latter definition will be considered for this study, as it helps the researchers to develop a conclusive view regarding the importance of commitment to customers and businesses alike.

Johnes et al. (2010) and Hammouri et al. (2021) illustrated that the three dimensions of the commitment model can be considered as emotional (affective), moral (normative) and rational (calculative). Notwithstanding, previous researchers in the field considered dimensions of commitment as affective commitment which is regarded as the willingness to maintain the relationship; calculative (continuance) commitment is regarded as the obligation to maintain the relationship; while normative commitment is regarded as the feeling that persuade the customer to maintain the relationship (Gruen et al., 2000; Kelly, 2004). As discussed above, this model was widely accepted and used in many empirical studies that were related to organizational behavioral literature as well as other research disciplines.

\subsubsection{Affective Commitment and customer loyalty}

Affective commitment is regarded as the emotional connection that ensures a positive relationship between customers and the firm (Morgan \& Hunt, 1994). This definition is an addition to Meyer and Allen's (1991) definition who suggested that "Affective commitment is" the sentimental connection between customers and the company or the service provider. Both definitions aim at ensuring and maintaining the "emotional attachment" and connection between the customers and the businesses they deal with.

Researchers in affective commitment have studied this dimension from different perspectives. Johnson et al. (2001) studied the relationship between affective commitment from one side with retention and referrals from the other side. Their study was applied to different research settings including train transportation, airlines, service stations, and banks. The study result signposts that the affective dimension positively influences the retention and referrals. Whereas Johnson et al. (2006) proposed that there are several aspects used to measure affective commitment such as happiness, belonging, recognition, and perception of attachment. They also suggest that affective commitment is strongly related to loyalty. This was also proposed by (Verhoef, 2003; Al-Gasawneh et al., 2020). The latter conducted research about affective commitment from the perspectives of relationship and belonging.

Besides, Shukla et al. (2016) studied the three-dimensional model of commitment and argued all three dimensions have a role towards customer commitment, but 'effective dimension' is suggested to uplift the relationship between customer commitment and loyalty. Based on this, the following hypothesis is proposed:

\section{$\mathbf{H}_{1}$ : Affective commitment is positively related to customer loyalty.}

\subsubsection{Normative Commitment and customer loyalty}

Normative commitment is a concept that points out to customers with the sense of moralistic commitment towards an institution (Bansal et al., 2004). This shows that normative commitment is connected with emotions and the concept of maintaining a relationship between customers and providers (Meyer \& Herscovitch 2001; Kelly, 2004; Gruen et al., 2000). Ajzen and Fishbein (1980) and Ajzen (1980) argued that based on the reasoned action theory, normative commitment is perceived as a result of two main aspects: internally and externally. The first is suggested to be as an influence of personal belief and nature. While the second is suggested to be a result of "social pressure" from family, co-workers and/or friends. About this study, both determinants will be related to normative commitment (internal values and external norms). Foxall et al. (1998) argued 
that the subjective norms drivers that influence normative commitment include the pressure individuals feel when they have to deal with the social environment that surrounds them. As a result, these individuals compare their attitudes and acts in accordance with their social groups. From one side, normative commitment was found to positively influence customer loyalty (Dick \& Basu, 1994). Parawansa (2018) found that the dimensions of commitment influence customer retention. While from the other side, it was found to negatively affect the intention of switchover (Nysveen et al., 2005). The differences between the results among researchers support the idea that normative commitment has attitudinal components that are significant in clarifying the "psychological attachment" to a certain provider, which is different from the desire to commitment and perceived cost. Bansal et al. (2004) studied the effect of commitment of switchover intention in an auto-repair industry. They found that among the three components of commitment, normative commitment, has the highest negative effect on the intention to switchover. In normative commitment, customers maintain the relationship because they believe that they are ought to do so (Sherma et al., 2015). This relationship is consistent with the internal values and external norms of customers. Therefore, the following hypothesis is proposed

\section{$\mathbf{H}_{2}$ : Normative commitment is positively related to customer loyalty.}

\subsubsection{Calculative Commitment and customer loyalty}

Meyer et al. (1993) defined calculative as the cost related to departing from an institution. Continuance commitment is defined as the "perceived cost associated with leaving the organization" (Meyer et al., 1993, p.539). Hammouri et al. (2021) pointed out that recognition of the cost has two folds, first, the switchover cost and second, the affordability of other sources. Calculative (continuance) commitment is associated with the cost related to the switching intention and depart the firm (Gruen et al., 2000). Moreover, calculative (cost-based) commitment has three main aspects where all are directly linked to the shortfall of other options such as the absence of genuine alternatives, apparent barriers to leaving the organization, and the cost associated with switchover (Andreassen \& Olsen, 2008; Al-Gasawneh et al., 2020). Research in organizational behavior literature outlines that calculative commitment includes both the cost associated with leaving as well as the availability of other alternatives in the market. However, for this study, calculative commitment that is linked to the cost related to exit the organization is going to be considered. This is because the banking service sector included many alternatives, and the availability of other alternatives is obvious. Henceforth, calculative commitment drives customers into preserving the relationships that already exist with organization (Bansal et al., 2004). From a different point of view, many researchers found calculative commitment to be negatively related to the intention of switchover to other providers (Fullerton, 2003; Gustafsson et al., 2005; Fullerton, 2005; Bansal et al., 2004). In Gustafsson et al. (2005) study, researchers studied the connection between commitment and retention and found that cost-based (calculative commitment) is negatively related to retention. Researcher (e.g., Johnson et al., 2006) recommended future researchers to further study the calculative commitment dimension. However, they stressed on researching in the area where the switchover boundaries are most significant such as banks. Thus, the following hypothesis is proposed:

\section{H3: Calculative commitment is positively related to customer loyalty.}

\subsection{E-service quality as a moderating variable}

Service quality (SERVQUAL) indicates a non-internet, but a direct interaction between customers and the companies. SERVQUAL has always been regarded as a crucial element in any business to become successful (Blose et al., 2005; Parasuraman et al., 2005; Al-Gasawneh et al., 2021). According to Parasuraman et al. (1991), SERVQUAL is considered as a 'generic instrument' which means that it has broad applicability as it proposes good reliability and validity. Service quality has been discussed widely in the literature especially in the banking sector. Suhartanto et al. (2019) contended that for customers to be loyal towards the bank, they require to receive services with an impartial share of return. According to Oliver (1999) loyalty leads to commitment and re-use/re-purchase of a product or service and to resist any attempts from competitors. This applies to the banking sectors, where customers tend to maintain their relationship, be committed and loyal to the bank without being tempted by other banks once they receive high service quality (Saleh et al., 2017; Bakar et al., 2017; Al-Gasawneh \& AlAdamat, 2020). Nonetheless, in recent research the term e-service quality (e-SQ) started to emerge to include the use of interbased services. Al-dweeri et al. (2017) argued that in the literature of e-SQ, researchers did not come to a final agreement on the concept of e-SQ. However, the widely accepted definition for e-SQ was proposed by Parasuraman et al. (2005). They defined it as "... the extent to which a web site facilitates efficient and effective shopping, purchasing and delivery". To comply with the definition, executives in the banking sector are required to understand the way customers evaluate electronic customer service for them to have the ability to improve the services quality to build a continuous and successful relationship with their customers.

The use of e-SQ channels is a key factor in preserving both customer's commitment and loyalty alike (Joseph \& Stone, 2003). Further, Zhu et al. (2002) proposed that both theory and practice have shown that e-SQ represents a positive experience for customers thenceforward leads them to continue with their institution (bank). Nonetheless, as has been discussed previously, commitment and loyalty are inconsistent especially when the three commitment constructs are studied in relation to customer loyalty. It was found that normative and affective commitment have negative effect on switchover intention and customer loyalty (Bansal \& Taylor, 1999; Bansal et al., 2004; Fullerton, 2003; Fullerton, 2005; Nysveen et al., 2005). Consequently, 
with (Al-Hawari, 2011) recognized the positive relationship presumed between e-SQ and commitment from one side, in addition to e-SQ and loyalty from the other. As well as given the previous discussion in the literature, it seems unlikely that the relationship between customer commitment and loyalty are moderated by e-service quality. Explicitly, it appears inconvenient that there would be differences in the extent of customers' commitment on customers' switchover intention thus loyalty. Therefore, it is only feasible to balance the relationship among the previous. Thus, the following hypotheses are proposed:

H4: The relationship between customer Affective commitment and loyalty is moderated by e-service quality.

H5: The relationship between customer Normative Commitment and loyalty is moderated by e-service quality

H6: The relationship between customer Calculative Commitment and loyalty is moderated by e-service quality

\section{Methods}

To evaluate the hypothesis, a self-reported questionnaire was created. The agreement statements were asked on a 7-point Likert scale. The banking service sector in Jordan was investigated as a case study. Customers were invited to answer questions about customer loyalty for the bank to improve the services it provides to its customers. To avoid carryover effects, the questionnaire was sent via an electronic link with each item on its own page.

The measurement scales were derived from organizational behavior literature (e.g., Meyer \& Allen 1991) as well as relationship marketing literature (e.g., Bansal et al., 2004). Meyer and Allen (1991) provided the items for evaluating emotional commitment, normative commitment, and cost-based commitment; Meyer and Allen (1991) provided the items for measuring affective commitment, normative commitment, and cost-based commitment (1996). To meet the banking sector's setting, phrasing changes were made.

The customer's goal to stay in the current and future, to do more business, and positive word of mouth actions were used to operationalize the loyalty notion. Repatronage intentions and word-of-mouth intentions can be understood as two distinct structures (Soderlund, 2006). Johnson, Herrmann, and Huber (2006) discovered that the term "loyalty intention" encompasses both patronage and word-of-mouth. For the purposes of this study, I believe that loyalty should be considered as a single construct that encompasses both patronage intents and positive word of mouth.

From Zeithaml, Berry, and Parasuraman's study, three questions evaluating good word-of-mouth were adopted (1996). Many previous academic studies in relationship marketing, such as Fullerton (2003), Fullerton (2005), Verhoef, Franses, and Hoekstra (2002), employed these particular items, and the items were widely used and demonstrated to be reliable in numerous situations. The additional items for the intention to stay questions were taken from Hansen et al. (2003), who assessed it with two items. The first question assesses the intention to preserve the current connection, while the second measures the intention to keep the relationship in the near future. Modifications in wording were made to obtain a better fit within the context of the study. Last, another question was added by the researcher to loyalty measurement, which focuses on the intention to do more business with the bank When a consumer required professional translation, the inquiries were translated into Arabic. In many cases, the items changed to fit the research setting of banking services. Additional academics' perspectives were solicited and offered to ensure that the questions were important to banking clients and measured what each construct was intended to test. In addition, before implementing the questionnaire, the present study conducted a pilot test with a group of people to ensure that the questions are simple to answer and coherent.

\section{Result}

There were 400 questionnaires received in all. 67 of these were missing information. As a result, 333 surveys could be used for analysis.

\subsection{Measurement Model}

The five major first-order variables in this study are affective commitment, normative commitment, calculative commitment, e-service quality, and client loyalty. In this study, convergent and discriminant validity were used to assess the measurement model. The convergent validity research looks at the composite reliability, average variance extract (AVE), and factor loading. Therefore, Table 1 summarizes the findings. As can be seen, each item had a loading more than 0.5, AVE values greater than 0.5 , and $\mathrm{CR}$ values greater than 0.7 . 
Table 1

Measurement model

\begin{tabular}{|c|c|c|c|c|}
\hline First order Construct & Items & Factor loading & $\mathbf{C R}$ & AVE \\
\hline \multirow[t]{6}{*}{ Affective Commitment } & AC 1 & 0.814 & 0.874 & 0.634 \\
\hline & $\mathrm{AC} 2$ & 0.790 & & \\
\hline & AC 3 & 0.764 & & \\
\hline & AC 4 & 0.821 & & \\
\hline & AC 5 & 0.778 & & \\
\hline & $\mathrm{AC} 6$ & 0.890 & & \\
\hline \multirow[t]{4}{*}{ Normative commitment } & $\mathrm{NC} 1$ & 0.860 & 0.833 & 0.626 \\
\hline & $\mathrm{NC} 2$ & 0.759 & & \\
\hline & $\mathrm{NC} 3$ & 0.750 & & \\
\hline & $\mathrm{NC} 4$ & 0.843 & & \\
\hline \multirow[t]{4}{*}{ Calculative Commitment } & $\mathrm{CC} 1$ & 0.753 & 0.881 & 0.650 \\
\hline & CC 2 & 0.866 & & \\
\hline & $\mathrm{CC} 3$ & 0.713 & & \\
\hline & $\mathrm{CC} 4$ & 0.880 & & \\
\hline \multirow{17}{*}{ e-service quality } & E-SQ 1 & 0.811 & 0.944 & 0.849 \\
\hline & E-SQ 2 & 0.897 & & \\
\hline & E-SQ 3 & 0.929 & & \\
\hline & E-SQ 4 & 0.909 & & \\
\hline & E-SQ 5 & 0.860 & & \\
\hline & E-SQ 6 & 0.936 & & \\
\hline & E-SQ 7 & 0.791 & & \\
\hline & E-SQ 8 & 0.866 & & \\
\hline & E-SQ 9 & 0.888 & & \\
\hline & E-SQ 10 & 0.845 & & \\
\hline & E-SQ 11 & 0.911 & & \\
\hline & E-SQ 12 & 0.845 & & \\
\hline & E-SQ 13 & 0.806 & & \\
\hline & E-SQ 14 & 0.937 & & \\
\hline & E-SQ 15 & 0.779 & & \\
\hline & E-SQ 16 & 0.910 & & \\
\hline & E-SQ 17 & 0.861 & & \\
\hline \multirow[t]{6}{*}{ Customer loyalty } & CL 1 & 0.862 & 0.940 & 0.759 \\
\hline & CL 2 & 0.848 & & \\
\hline & CL 3 & 0.905 & & \\
\hline & CL 4 & 0.861 & & \\
\hline & CL 5 & 0.878 & & \\
\hline & CL 6 & 0.843 & & \\
\hline
\end{tabular}

The HTMT construct measures the model's discriminant validity (see Henseler, 2015; Ngah et al., 2021), and the reported HTMT construct values in this study ranged from 0.357 to 0.887 . The findings are summarized in Table 3 . Therefore, each latent concept assessment in this study was exclusively discriminatory vs the others, according to Henseler et al. (2015).

Table 2

Discriminant validity (HTMT)

\begin{tabular}{|c|c|c|c|c|c|}
\hline & $\mathbf{A C}$ & NC & $\mathrm{CC}$ & E-SQ & CL \\
\hline AC & & & & & \\
\hline NC & 0.675 & & & & \\
\hline $\mathrm{CC}$ & 0.887 & 0.409 & & & \\
\hline E-SQ & 0.671 & 0.713 & 0.584 & & \\
\hline CL & 0.357 & 0.573 & 0.826 & 0.622 & \\
\hline
\end{tabular}

The measurement model's convergent and discriminant validity research findings demonstrate the measuring scale's appropriateness and accuracy in assessing the constructs and their related items in the CFA model. Therefore, the analytical findings for convergent validity and discriminant validity are presented in Tables 1 and 2, respectively.

\subsection{Structural model}

According to Hair et al., this research looked at the structural model, $\mathrm{R}^{2}$, beta, $\mathrm{t}$-values using bootstrapping with a 500 resample, predictive relevance $\left(\mathrm{Q}^{2}\right)$, and VIF (2016). The calculated $\mathrm{R}^{2}$ value for online shopping intention (CL) was 0.589 , suggesting a 58.9\% degree of variance in CL, as shown in Table 3. Chin's recommended cut-off point of 0.19 is supported by this finding (1998). Consequently, the predictors contribute to the clarification of the concept. Furthermore, the $\mathrm{Q}^{2}$ value linked with CL was 0.280 , which is significantly greater than zero, supporting Chin's prediction model's validity (2010). Therefore, the appropriateness of the model is validated. The model, too, showed a high level of predictive relevance. The VIF values were 1.343, 1.105, 1.567, 2.652, 2.669, 2.438, all less than 5, as Hair et al. indicated (2016). 


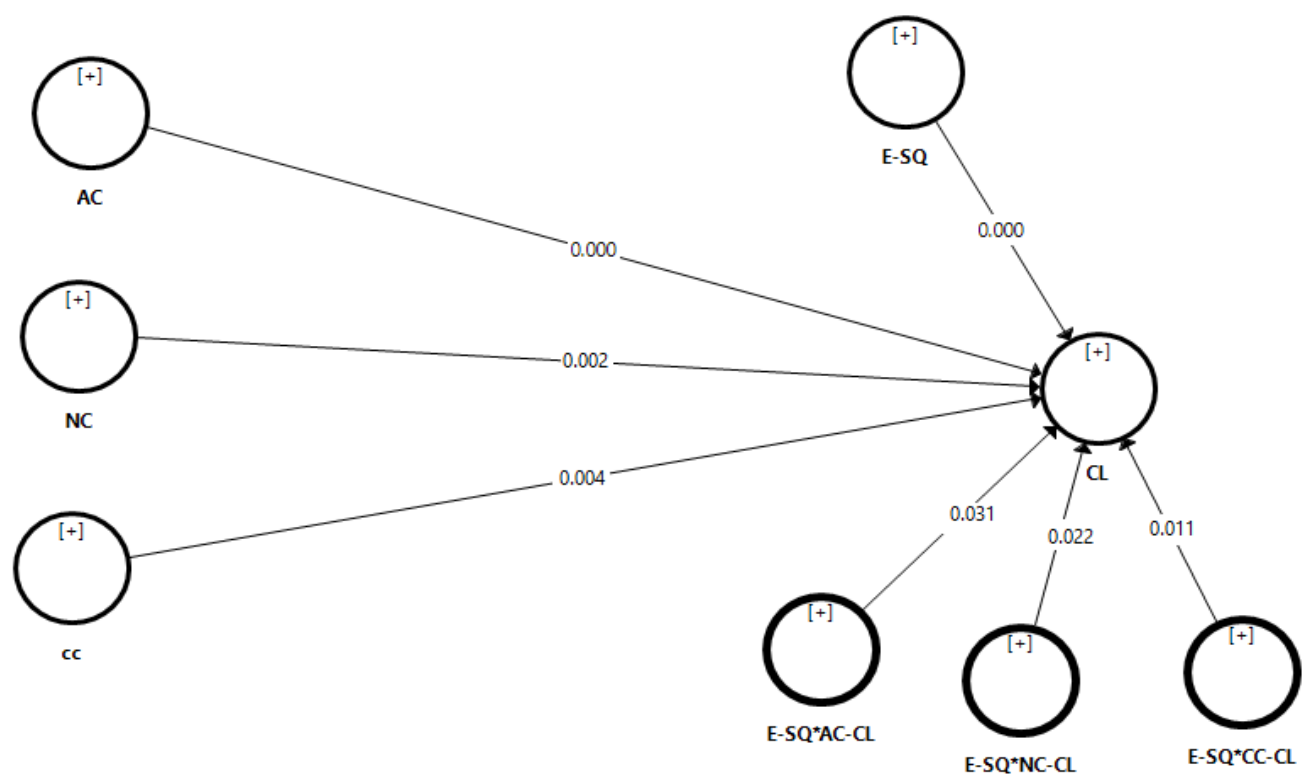

Fig. 1. The results of testing the hypothesis

Table 3 and Fig. 1 show that the AC predictor has a favorable effect on CL, with values of $=0.383$ and $p=0.0000 .05$. This indicates that $\mathrm{H} 1$ is supported ( $\mathrm{AC}$ on $\mathrm{CL}$ ); $\mathrm{NC}$ predictor has a positive influence on $\mathrm{CL}$, with values of $=0.117$ and $\mathrm{p}=0.000$ 0.05 , This indicates that $\mathrm{H} 2$ was in supported; a positive influence of the $\mathrm{CC}$ predictor on $\mathrm{CL}$, with values of $=0.320$ and $\mathrm{p}=$ 0.0000 .05 , indicating that $\mathrm{H} 3$ was in supported. Meanwhile, H4, H5, and H6 concern the moderating influence of E-SQ on the link between AC and CL, NC and CL, and CC and CL, with the following results: $=0.289$ and $\mathrm{p}=0.0030 .05$, $=0.421$ and $\mathrm{p}=0.0030 .05,=0.338$. $\mathrm{p}=0.0030 .05$ and $\mathrm{p}=0.0030 .05$. The interaction impact between $\mathrm{AC}-\mathrm{CL} ; \mathrm{NC}-\mathrm{CL}$; CC $\mathrm{CL}$ via ESQ $(\mathrm{H} 4, \mathrm{H} 5, \mathrm{H} 6)$ is supported based on the preceding result.

Table 3

The summary of testing the hypotheses

\begin{tabular}{|c|c|c|c|c|c|c|c|}
\hline & S. $\beta$ & S. D & $\mathbf{R}^{2}$ & $\mathbf{Q}^{2}$ & VIF & T-value & P Values \\
\hline $\mathbf{A C}-\mathbf{C L}$ & 0.383 & 0.134 & 0.589 & 0.280 & 1.343 & 2.858 & 0.000 \\
\hline $\mathbf{N C}-\mathbf{C L}$ & 0.117 & 0.050 & & & 1.105 & 2.340 & 0.000 \\
\hline $\mathbf{C C}-\mathbf{C L}$ & 0.320 & 0.049 & & & 1.567 & 6.530 & 0.000 \\
\hline$A C-C L * E S Q$ & 0.289 & 0.034 & 0.621 & & 2.652 & 8.500 & 0.031 \\
\hline $\mathrm{NC}-\mathrm{CL}^{*} \mathrm{ESQ}$ & 0.421 & 0.065 & & & 2.669 & 6.476 & 0.022 \\
\hline $\mathrm{NC}-\mathrm{CL}^{*} \mathrm{ESQ}$ & 0.338 & 0.074 & & & 2.438 & 4.567 & 0.011 \\
\hline
\end{tabular}

\section{Conclusion}

The conclusion drawn from this research discourses the hypotheses associated with commitment dimensions and their effect on loyalty. The results suggest that affective commitment has the highest positive influence on loyalty, this therefore signposted that affective attachment has an essential role in the relationship between customers and their banks. This result is followed by normative commitment, and lastly calculative commitment, where the latter has the weakest impact on customer loyalty in the banking setting in Jordan.

The results discussed in this study shed light on important recommendations to practitioners. They need to understand the importance of each commitment type and pay attention to the priority, which is effective commitment, then normative and finally calculative. Understanding their importance will lead the banks to recognize the reasons customers maintain and cherish their relationships with their banks or on the other hand why customers are weakly attached and are easily intended to switch. According to that, banks need to plan their marketing activities by considering customers' priorities when it comes to their relationships with their banks.

\section{Limitations of the Study \& Future Research}

This study was conducted in a cross-sectional manner. Longitudinal study will be able to better evaluate and identify the attitudinal components of commitment dimensions and loyalty, as well as their variations over time. Although it has been 
suggested by other scholars that commitment may have more than three dimensions (e.g., five dimensions as in Keiningham et al. 2015), the questions within the questionnaire of this study appeared to be thorough and contained numerous aspects under each commitment dimension that fit the study's setting (banking sector). Other industries could be investigated as part of this research, and a comparison of the industries could yield more solid and/or informative results. Furthermore, crosscultural research may shed more light on the study's generalizability. Customer share, in addition to customer loyalty, could be a dependent variable; however, this may necessitate access to a company's database, which may be challenging.

\section{References}

Afsar, B., Rehman, Z. U., \& Shahjehan, A. (2010). Determinants of customer loyalty in the banking sector: The case of Pakistan. African Journal of Business Management, 4(6), 1040-1047.

Ajzen, I., \& Fishbein, M. (1980). Understanding Attitudes and Predicting Social Behavior. United States: Prentice-Hall.

Ajzen, I. (1980). Understanding attitudes and predicting social behavior. Englewood Cliffs.

Al-Adamat, A., Al-Gasawneh, J., \& Al-Adamat, O. (2020). The impact of moral intelligence on green purchase intention. Management Science Letters, 10(9), 2063-2070.

Al-dweeri, R. M., Obeidat, Z. M., Al-dwiry, M. A., Alshurideh, M. T., \& Alhorani, A. M. (2017). The impact of e-service quality and e-loyalty on online shopping: moderating effect of e-satisfaction and e-trust. International Journal of Marketing Studies, 9(2), 92-103.

Al-Gasawneh, J. A., \& Al-Adamat, A. M. (2020). The relationship between perceived destination image, social media interaction and travel intentions relating to Neom city. Academy of Strategic Management Journal, 19(2), 1-12.

Al-Gasawneh, J. A., Anuar, M. M., Dacko-Pikiewicz, Z., \& Saputra, J. (2021). The impact of customer relationship management dimensions on service quality. Polish Journal of Management Studies, 23(2), 24-44.

Al-Gasawneh, J., Al-Wadi, M., Al-Wadi, B., Alown, B., \& Nuseirat, N. (2020). The Interaction Effect of Comprehensiveness Between Social Media and Online Purchasing Intention in Jordanian Pharmacies. International Association of Online Engineering, Retrieved October 13, 2020 from https://www.learntechlib.org/p/217794/

Alghasawneh, L. A. S., Akhorshaideh, A. H., Alharafsheh, M., Ghasawneh, A., Al-Gasawneh, J. A., \& Al-Hadid, A. Y. (2021). Determinants of Supply Chain Management Practices in Jordanian Pharmaceutical Firms. Solid State Technology, 64(2), 2986-3001.

Al-Hawari, M. A. (2011). Automated service quality as a predictor of customers' commitment: a practical study within the UAE retail banking context. Asia Pacific Journal of Marketing and Logistics, 23(3), 346-366.

Alkhawaldeh, A., Al-Salaymeh, M., Alshare, F., \& Eneizan, B. M. (2017). The effect of brand awareness on brand loyalty: Mediating role of brand commitment. European Journal of business and Management, 9(36) 38-47.

Allen, N. J., \& Meyer, J. P. (1990). The measurement and antecedents of affective, continuance and normative commitment to the organization. Journal of occupational psychology, 63(1), 1-18.

Allen, N. J., \& Meyer, J. P. (1996). Affective, continuance, and normative commitment to the organization: An examination of construct validity. Journal of vocational behavior, 49(3), 252-276.

Anderson, J. C., \& Narus, J. A. (1991). Partnering as a focused market strategy. California Management Review, $33(3), 95-$ 113.

Andreassen, T. W., \& Olsen, L. L. (2008). The impact of customers' perception of varying degrees of customer service on commitment and perceived relative attractiveness. Managing Service Quality: An International Journal, 18(4), $309-328$.

Bakar, J. A., Clemes, M. D., \& Bicknell, K. (2017). A comprehensive hierarchical model of retail banking. International Journal of Bank Marketing, 35(4), 662-684.

Bansal, H. S., \& Taylor, S. F. (1999). The service provider switching model (spsm) a model of consumer switching behavior in the services industry. Journal of service Research, 2(2), 200-218.

Bansal, H., Irving, P. G., \& Taylor, S. F. (2004). A three component model of customer commitment to service provider. Academy of Marketing Science, 32 (3), 234-250.

Brown, T. J., Barry, T. E., Dacin, P. A., \& Gunst, R. F. (2005). Spreading the word: Investigating antecedents of consumers' positive word-of-mouth intentions and behaviors in a retailing context. Journal of the academy of marketing science, 33(2), 123-138.

Daikh, J. (2015). A research proposal: the relationship between customer satisfaction and consumer loyalty. MBA Student Scholarship, (42).

Dick, A. S., \& Basu, K. (1994). Customer loyalty: toward an integrated conceptual framework. Journal of the academy of marketing science, 22(2), 99-113.

Dwyer, F. R., Schurr, P. H., \& Oh, S. (1987). Developing buyer-seller relationships. Journal of marketing, 51(2), 11-27.

Johnson, M. D., Gustafsson, A., Andreassen, T. W., Lervik, L., \& Cha, J. (2001). The evolution and future of national customer satisfaction index models. Journal of economic Psychology, 22(2), 217-245.

Fatima, J. K., \& Mascio, R. D. (2020). Synchronizing relational benefits with customer commitment profiles. Journal of Strategic Marketing, 28(4), 366-378.

Fatima, J. K., Razzaque, M. A., \& Di Mascio, R. (2015). Modelling roles of commitment on rapport and satisfaction. International Journal of Bank Marketing, 33(3), 261-275.

Foxall, G. R., Goldsmith, R. E., \& Brown, S. (1998). Consumer psychology for marketing (Vol. 1). Cengage Learning EMEA.

Fullerton, G. (2003). When does commitment lead to loyalty? Journal of service research, 5(4), 333-344. 
Fullerton, G. (2005). How commitment both enables and undermines marketing relationships. European journal of marketing, $39(11 / 12), 1372-1388$.

Fullerton, G. (2014). The moderating effect of normative commitment on the service quality-customer retention relationship. European journal of marketing, 48 (3/4), 657-673.

Gruen, T. W., Summers, J. O., \& Acito, F. (2000). Relationship marketing activities, commitment, and membership behaviors in professional associations. Journal of marketing, 64(3), 34-49.

Gustafsson, A., Johnson, M. D., \& Roos, I. (2005). The effects of customer satisfaction, relationship commitment dimensions, and triggers on customer retention. Journal of marketing, 69(4), 210-218.

Hammouri, Q., Al-Gasawneh, J. A., Nusairat, N. M., Hanandeh, A., \& Barakat, S. (2021). The Determinants of Trust and its Influence on Online Buying Intention: An Empirical Study on Social Commerce in Jordan. Annals of the Romanian Society for Cell Biology, 4522-4539.

Hansen, H., Sandvik, K., \& Selnes, F. (2003). Direct and indirect effects of commitment to a service employee on the intention to stay. Journal of Service Research, 5(4), 356-368.

Hawamleh, A. M. A., Alorfi, A. S. M., Al-Gasawneh, J. A., \& Al-Rawashdeh, G. (2020). Cyber Security and Ethical Hacking: The Importance of Protecting User Data. Solid State Technology, 63(5), 7894-7899.

Herscovitch, L., \& Meyer, J. P. (2002). Commitment to organizational change: extension of a three-component model. Journal of applied psychology, 87(3), 474-487

Jaros, S. J., Jermier, J. M., Koehler, J. W., \& Sincich, T. (1993). Effects of continuance, affective, and moral commitment on the withdrawal process: An evaluation of eight structural equation models. Academy of management Journal, 36 (5), 951 995.

Johnson, M. D., Gustafsson, A., Andreassen, T. W., Lervik, L., \& Cha, J. (2001). The evolution and future of national customer satisfaction index models. Journal of economic Psychology, 22(2), 217-245.

Johnson, M. D., Herrmann, A., \& Huber, F. (2006). The evolution of loyalty intentions. Journal of marketing, 70(2), 122132.

Jones, T., \& Taylor, S. F. (2007). The conceptual domain of service loyalty: how many dimensions?. Journal of services marketing, 21(1), 36-51.

Jones, T., Fox, G. L., Taylor, S. F., \& Fabrigar, L. R. (2010). Service customer commitment and response. Journal of Services Marketing, 24(1), 16-28.

Jones, T., Taylor, S. F., \& Bansal, H. S. (2008). Commitment to a friend, a service provider, or a service company-are they distinctions worth making?. Journal of the academy of Marketing Science, 36(4), 473.

Joseph, M., \& Stone, G. (2003). An empirical evaluation of US bank customer perceptions of the impact of technology on service delivery in the banking sector. International Journal of Retail \& Distribution Management, 31(4), $190-202$.

Keiningham, T. L., Frennea, C. M., Aksoy, L., Buoye, A., \& Mittal, V. (2015). A five-component customer commitment model: implications for repurchase intentions in goods and services industries. Journal of Service Research, 18(4), 433450.

Kelly, S. J. (2004). Measuring attitudinal commitment in business-to-business channels. Marketing Intelligence \& Planning, 22(6/7), 636-651.

Macintosh, G., \& Lockshin, L. S. (1997). Retail relationships and store loyalty: a multi-level perspective. International Journal of Research in marketing, 14(5), 487-497.

Meyer, J. P., Allen, N. J., \& Smith, C. A. (1993). Commitment to organizations and occupations: Extension and test of a threecomponent conceptualization. Journal of applied psychology, 78(4), 538-551.

Meyer, J. P., \& Allen, N. J. (1991). A three-component conceptualization of organizational commitment. Human resource management review, $1(1), 61-89$.

Meyer, J. P., \& Herscovitch, L. (2001). Commitment in the workplace: Toward a general model. Human resource management review, 11(3), 299-326.

Morgan, R. M., \& Hunt, S. D. (1994). The commitment-trust theory of relationship marketing. Journal of marketing, 58(3), 20-38.

Ngah, A. H., Gabarre, S., Han, H., Rahi, S., Al-Gasawneh, J. A., \& Park, S. H. (2021). Intention to purchase halal cosmetics: do males and females differ? A multigroup analysis. Cosmetics, 8(1), 19.

Nysveen, H., Pedersen, P. E., \& Thorbjørnsen, H. (2005). Intentions to use mobile services: Antecedents and cross-service comparisons. Journal of the academy of marketing science, 33(3), 330-346.

Oliver, R. L. (1999). Whence consumer loyalty?. Journal of marketing, 63(4_suppl1), 33-44.

Osuna Ramírez, S. A., Veloutsou, C., \& Morgan-Thomas, A. (2017). A systematic literature review of brand commitment: Definitions, perspectives and dimensions. Athens journal of business and economics, 3(3), 305-332.

Parasuraman, A., Berry, L., \& Zeithaml, V. (1991). Refinement and reassessment of the SERVQUAL scale. Journal of retailing, 67(4), 420-450.

Parasuraman, A., Zeithaml, V. A., \& Malhotra, A. (2005). ES-QUAL: A multiple-item scale for assessing electronic service quality. Journal of service research, 7(3), 213-233.

Rather, R. A., \& Sharma, J. (2017). The effects of customer satisfaction and commitment on customer loyalty: Evidence from the hotel industry. JOHAR, 12(2), 41.

Reinartz, W., Krafft, M., \& Hoyer, W. D. (2004). The customer relationship management process: Its measurement and impact on performance. Journal of marketing research, 41(3), 293-305. 
Rusbult, C. E. (1980). Commitment and satisfaction in romantic associations: A test of the investment model. Journal of experimental social psychology, 16(2), 172-186.

Saleh, M. A., Quazi, A., Keating, B., \& Gaur, S. S. (2017). Quality and image of banking services: a comparative study of conventional and Islamic banks. International Journal of Bank Marketing, 35(6), 878-902.

Shukla, P., Banerjee, M., \& Singh, J. (2016). Customer commitment to luxury brands: Antecedents and consequences. Journal of Business Research, 69(1), 323-331.

Söderlund, M. (2006). Measuring customer loyalty with multi-item scales: A case for caution. International journal of service industry management, 17 (1), 76-98.

Stanley, L., Vandenberghe, C., Vandenberg, R., \& Bentein, K. (2013). Commitment profiles and employee turnover. Journal of Vocational Behavior, 82(3), 176-187.

Suhartanto, D., Gan, C., Sarah, I. S., \& Setiawan, S. (2019). Loyalty towards Islamic banking: service quality, emotional or religious driven?. Journal of Islamic Marketing, 17.

Verhoef, P. C. (2003). Understanding the effect of customer relationship management efforts on customer retention and customer share development. Journal of marketing, 67(4), 30-45.

Verhoef, P. C., Franses, P. H., \& Hoekstra, J. C. (2002). The effect of relational constructs on customer referrals and number of services purchased from a multiservice provider: does age of relationship matter?. Journal of the academy of marketing science, 30(3), 202-216.

Wästerlund, D. S., \& Kronholm, T. (2017). Family forest owners' commitment to service providers and the effect of association membership on loyalty. Small-scale forestry, 16(2), 275-293.

Zeithaml, V. A., Berry, L. L., \& Parasuraman, A. (1996). The behavioral consequences of service quality. Journal of marketing, 60(2), 31-46.

Zhu, F. X., Wymer, W., \& Chen, I. (2002). IT-based services and service quality in consumer banking. International journal of service industry management, 13(1), 69-90.

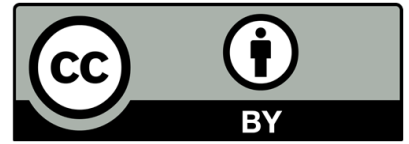

(C) 2022 by the authors; licensee Growing Science, Canada. This is an open access article distributed under the terms and conditions of the Creative Commons Attribution (CC-BY). license (http://creativecommons.org/licenses/by/4.0/). 